\title{
Redox Properties of CU(I) Camphor Hydrazone Complexes
}

\author{
M. Fernanda N.N. Carvalho, Tiago A. Fernandes \\ CQE, Complexo I, Instituto Superior Técnico, Technical University of Lisbon, \\ Av. Rovisco Pais 1049-001 Lisboa, Portugal
}

Received 7 October 2010; accepted 2 February 2011

\begin{abstract}
The electrochemical properties of the one-dimensional coordination polymers $\left[\{\mathrm{CuX}\}_{2}\left(\mathrm{YNC}_{10} \mathrm{H}_{14} \mathrm{O}\right)\right]_{\mathrm{n}}\left(\mathrm{X}=\mathrm{Cl}: \mathrm{Y}=\mathrm{NMe}_{2}\right.$ 1a, $\mathrm{Y}=\mathrm{NHMe} \mathbf{1 b}, \mathrm{Y}=\mathrm{NH}_{2} \mathbf{1 c} ; \mathrm{X}=\mathrm{Br}: \mathrm{Y}=\mathrm{NH}_{2}$ 2c) and dimers $\left[\left\{\mathrm{Cu}\left(\mathrm{YNC}_{10} \mathrm{H}_{14} \mathrm{O}\right)\right\}_{2}(\mu-\mathrm{X})_{2}\right]\left(\mathrm{X}=\mathrm{Cl}\right.$ : $\mathrm{Y}=\mathrm{NMe}_{2}$ 3a; $\mathrm{Y}=\mathrm{NHMe} 3 \mathbf{b} ; \mathrm{X}=\mathrm{Br}$ : $\left.\mathrm{Y}=\mathrm{NMe}_{2} \mathbf{4 a} ; \mathrm{Y}=\mathrm{NHMe} \mathbf{4 b}\right)$ were studied by cyclic voltammetry $(\mathrm{CV})$ and controlled potential electrolysis (CPE). All complexes display anodic and cathodic processes. The anodic processes involve the oxidation of the metal site $(\mathrm{Cu}(\mathrm{I}) \rightarrow \mathrm{Cu}(\mathrm{II}))$, while the cathodic processes are based on the ligand. The substituent (Y) at the camphor hydrazones $\left(\mathrm{YNC}_{10} \mathrm{H}_{14} \mathrm{O}\right)$ plays a relevant role in the electrochemical properties and reactivity of $\mathrm{Cu}(\mathrm{I})$ coordination polymers and $\mathrm{Cu}(\mathrm{I})$ dimmers, as corroborated by $\mathrm{CPE}$.
\end{abstract}

Keywords: cyclic voltammetry, controlled potential electrolysis, redox properties, coordination polymers, copper dimmers, camphor hydrazones.

\section{Introduction}

Palladium and platinum camphor imine $\left(\mathrm{L}=\mathrm{YNC}_{10} \mathrm{H}_{14} \mathrm{O}\right)$ complexes trans$\left[\mathrm{MX}_{2} \mathrm{~L}_{2}\right]$ are active catalysts for $\mathrm{C}-\mathrm{C}$ and $\mathrm{C}-\mathrm{O}$ bond formation $[1,2]$ a fact that stimulated the study of the ability of camphor hydrazones to coordinate other transition metals. As a consequence, the camphor hydrazones were found to react with copper halides $(\mathrm{CuX}: \mathrm{X}=\mathrm{Cl}, \mathrm{Br})$ forming $\mathrm{Cu}(\mathrm{I})$ complexes that may have polymer or dimer character [3] (Fig. 1). In particular, coordination polymers have high interest since they may be included in the category of hybrid nano-materials. Furthermore, the unusual structural arrangement of the copper units in the coordination polymers $\left[(\mathrm{CuX})_{2}\left(\mathrm{YNC}_{10} \mathrm{H}_{14} \mathrm{O}\right)\right]_{\mathrm{n}}$ challenged the study of the electrochemical properties of $\mathrm{Cu}(\mathrm{I})$ complexes, in order to evaluate if differences exist in the redox properties of the tetrahedral and linear copper units. The redox properties of the dimers were also studied because they convert to the related coordination polymers and the process can be reversed in mild experimental conditions [4].

\footnotetext{
* Corresponding author. E-mail address: fcarvalho@ist.utl.pt
} 

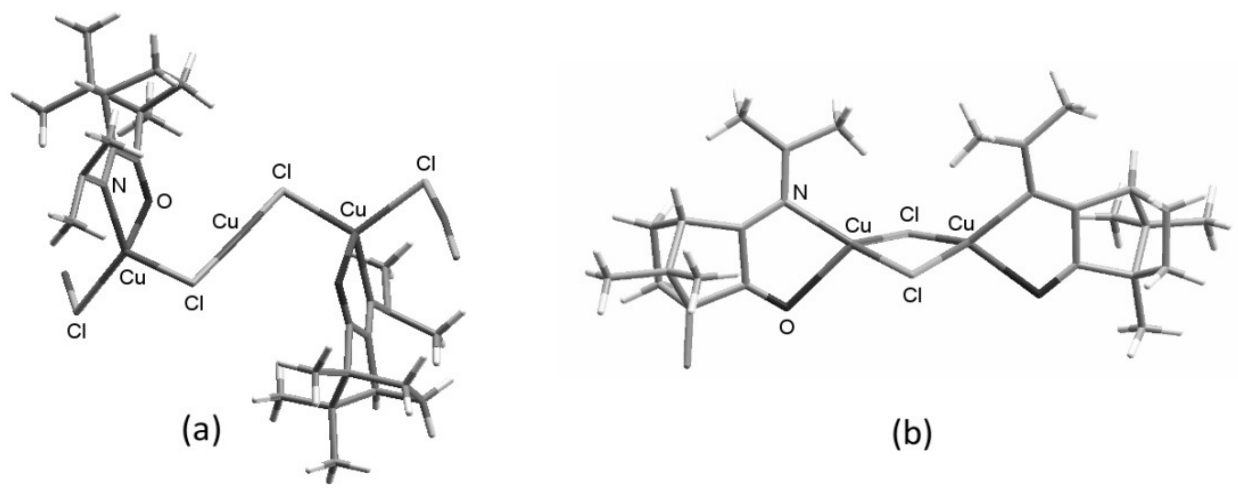

(b)

Figure 1. Structures of (a) coordination polymer $\left[(\mathrm{CuCl})_{2}\left(\mathrm{Me}_{2} \mathrm{NNC}_{10} \mathrm{H}_{14} \mathrm{O}\right)\right]_{\mathrm{n}}$ and (b) dimer $\left[\left\{\mathrm{Cu}\left(\mathrm{Me}_{2} \mathrm{NNC}_{10} \mathrm{H}_{14} \mathrm{O}\right)\right\}_{2}(\mu-\mathrm{Cl})_{2}\right]$ are depicted for clarification.

\section{Experimental}

All electrochemical studies were performed under dinitrogen using $\left[\mathrm{NBu}_{4}\right]\left[\mathrm{BF}_{4}\right]$ / THF (0.2 M) solution as electrolyte. A Pt wire was used as working electrode for $\mathrm{CV}$ and a Pt-gauze as working electrode for CPE. Potentials were measured at $200 \mathrm{mV} / \mathrm{s}$ using $\left[\mathrm{Fe}\left(\eta^{5}-\mathrm{C}_{5} \mathrm{H}_{5}\right)_{2}\right]^{0 /+}\left(\mathrm{E}_{1 / 2}=0.547 \mathrm{~V}\right.$ vs. SCE $)$ or alternatively $\mathrm{Me}_{2} \mathrm{NNC}_{10} \mathrm{H}_{14} \mathrm{O} \quad\left(E_{1 / 2}^{\text {red }}\right)=-2.01 \quad$ vs. $\left.\mathrm{SCE}\right)$ as internal references. A potentiostat/galvanostat Radiometer Analytical Voltammetry PST050 VoltaLab® equipment was used for cyclic voltammetry studies and a potentiostat/galvanostat Princeton Applied Research Model 273A for controlled potential electrolysis.

Complexes [2,3] and camphor ligands [4] were prepared by published methods. THF was purchased from Riedel-de Haën and $\left[\mathrm{NBu}_{4}\right]\left[\mathrm{BF}_{4}\right]$ / THF from Merck. THF was purified by published methods and distilled immediately before use.

\section{Results and discussion}

The electrochemical properties of complexes $\left[(\mathrm{CuX})_{2}\left(\mathrm{YNC}_{10} \mathrm{H}_{14} \mathrm{O}\right)\right]$ and $\left[(\mathrm{CuL})_{2}(\mu-\mathrm{X})_{2}\right]$ were studied by cyclic voltammetry $(\mathrm{CV})$ in THF. Controlled potential electrolysis (CPE) was performed at the potential of the anodic processes to establish the number of electrons transferred in the $\mathrm{Cu}(\mathrm{I}) \rightarrow \mathrm{Cu}$ (II) oxidation processes.

\section{CV studies}

Complexes $\left[(\mathrm{CuX})_{2}\left(\mathrm{YNC}_{10} \mathrm{H}_{14} \mathrm{O}\right)\right]_{\mathrm{n}}$ and $\left[\left\{\mathrm{Cu}\left(\mathrm{YNC}_{10} \mathrm{H}_{14} \mathrm{O}\right)\right\}_{2}(\mu-\mathrm{X})_{2}\right]$ display by cyclic voltammetry one oxidation and one reduction processes with some reversibility. Coordination polymers $\left[(\mathrm{CuX})_{2}\left(\mathrm{YNC}_{10} \mathrm{H}_{14} \mathrm{O}\right)\right]_{\mathrm{n}}$ have two distinct $\mathrm{Cu}$ (I) metal centres per structural unit that oxidize at close potentials, thus the anodic waves are not fully distinguishable and consequently a broad anodic wave is observed in the cyclic voltammogram of each complex. Variation of the scan 
rate $(50 \mathrm{mV} / \mathrm{s}$ to $1000 \mathrm{mV} / \mathrm{s})$ could not resolve completely the overlapped anodic waves, although in the case of $\mathbf{1 a}(v=200 \mathrm{mV} / \mathrm{s})$ two waves are visible (Fig. 2).

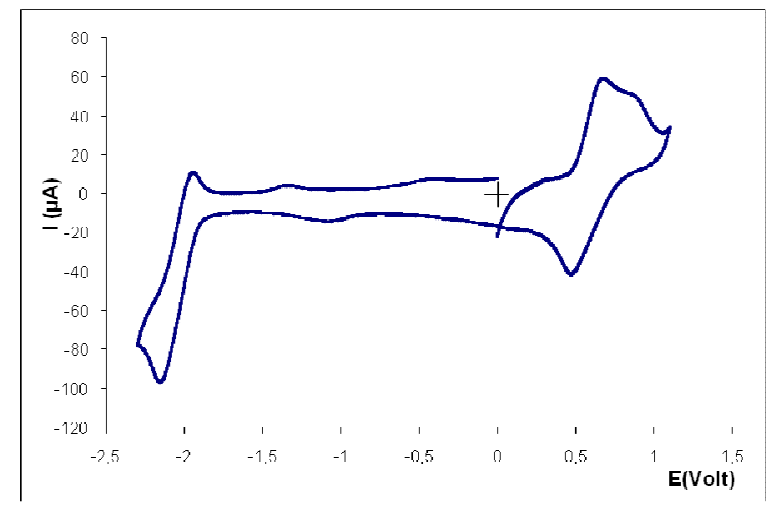

Figure 2. Cyclic voltammogram of $\left[(\mathrm{CuCl})_{2}\left(\mathrm{Me}_{2} \mathrm{NNC}_{10} \mathrm{H}_{14} \mathrm{O}\right)\right]_{\mathrm{n}}$ (Pt wire, $\left.\left[\mathrm{NBu}_{4}\right]\left[\mathrm{BF}_{4}\right] / \mathrm{THF}(0.2 \mathrm{M}), v=200 \mathrm{mV} / \mathrm{s}\right)$.

The potentials of the cathodic processes in complexes (Tables 1 and 2) do not differ much from those in the corresponding free camphor hydrazones (also measured in THF) that display irreversible (Y=NHMe: $E_{1 / 2}^{\text {red }}=-2.09 \mathrm{~V} ; \mathrm{Y}=\mathrm{NH}_{2}$, $\left.E_{1 / 2}^{\text {red }}=-1.99 \mathrm{~V}\right)$ or quasi reversible $\left(\mathrm{Y}=\mathrm{NMe}_{2}: E_{1 / 2}^{\text {red }}=-2.01 \mathrm{~V}\right)$ reduction processes. No big differences also exist between the above values of potential and those reported before [6] in agreement with the low sensitivity of the reduction processes to the characteristics of camphor hydrazone substituent (Y). In the cyclic voltammograms of camphor hydrazones ( $\mathrm{Y}=\mathrm{NHR}$ ) a small intensity irreversible cathodic wave (Y=NHMe, $\left.E_{1 / 2}^{\text {red }}=-1.16 \mathrm{~V} ; \mathrm{Y}=\mathrm{NH}_{2} E_{1 / 2}^{\text {red }}=-1.20 \mathrm{~V}\right)$ was attributed to the reduction of $\mathrm{NH}$.

Table 1. Cyclic voltammetry data ${ }^{a}$ for complexes $\left[(\mathrm{CuX})_{2} \mathrm{~L}\right]_{\mathrm{n}}$.

\begin{tabular}{cc|c|c|c}
\hline Complex & & $\mathrm{Y}$ & ${ }^{\mathrm{I}} \mathrm{E}_{1 / 2}^{\text {ox }}(\mathrm{V})$ & $\mathrm{E}_{1 / 2}^{\text {red }}(\mathrm{V})$ \\
\hline$\left[(\mathrm{CuCl})_{2}\left(\mathrm{YNC}_{10} \mathrm{H}_{14} \mathrm{O}\right)\right]_{\mathrm{n}}$ & $\mathbf{( 1 a )}$ & $\mathrm{NMe}_{2}$ & 0.61 & -2.04 \\
\hline$\left[(\mathrm{CuCl})_{2}\left(\mathrm{YNC}_{10} \mathrm{H}_{14} \mathrm{O}\right)\right]_{\mathrm{n}}$ & $\mathbf{( 1 b )}$ & $\mathrm{NHMe}$ & 0.58 & $-2.12^{\mathrm{b}}$ \\
\hline$\left[(\mathrm{CuCl})_{2}\left(\mathrm{YNC}_{10} \mathrm{H}_{14} \mathrm{O}\right)\right]_{\mathrm{n}}$ & $\mathbf{( 1 c )}$ & \multirow{2}{*}{$\mathrm{NH}_{2}$} & 0.63 & -2.04 \\
\cline { 1 - 1 } \cline { 5 - 6 }$\left[(\mathrm{CuBr})_{2}\left(\mathrm{YNC}_{10} \mathrm{H}_{14} \mathrm{O}\right)\right]_{\mathrm{n}}$ & $\mathbf{( 2 c})$ & & 0.62 & $-1.96^{\mathrm{c}}$
\end{tabular}

${ }^{\text {a }}$ Values $( \pm 10 \mathrm{mVolt})$ in THF ( $\left.\mathrm{v}=200 \mathrm{mV} / \mathrm{s}\right)$. Processes are quoted as reversible although they do not obey to the criteria $\mathrm{i}_{\mathrm{pa}} / \mathrm{i}_{\mathrm{pc}}=1$. ${ }^{\mathrm{b}} \mathrm{A}$ weak wave is observed at $E_{1 / 2}^{r e d}=-1.17 \mathrm{~V}$. ${ }^{\mathrm{c}}$ A weak wave is observed at $E_{1 / 2}^{\text {red }}=-1.64 \mathrm{~V}$.

The potentials of cathodic processes in complexes are consistent with ligand based processes, while the potentials of the anodic processes (Tables 1 and 2) are well in the range of the value of the oxidation of $\mathrm{CuCl}\left(E_{1 / 2}^{o x}=0.60 \mathrm{~V}\right.$, in THF). Thus the anodic processes in complexes were attributed to the $\mathrm{Cu}(\mathrm{I}) \rightarrow \mathrm{Cu}$ (II) oxidation. 
Table 2. Cyclic voltammetry data ${ }^{\mathrm{a}}$ for complexes $\left[(\mathrm{CuL})_{2}(\mu-\mathrm{X})_{2}\right](\mathrm{X}=\mathrm{Cl}, \mathrm{Br})$.

\begin{tabular}{l|c|c|c|c}
\hline \multicolumn{1}{c|}{ Complex } & & $\mathrm{Y}$ & ${ }^{\mathrm{I}} \mathrm{E}_{1 / 2}{ }^{\mathrm{ox}}(\mathrm{V})$ & $\mathrm{E}_{1 / 2}{ }^{\text {red }}(\mathrm{V})$ \\
\hline$\left[\left\{\mathrm{Cu}\left(\mathrm{YNC}_{10} \mathrm{H}_{14} \mathrm{O}\right)\right\}_{2}(\mu-\mathrm{Cl})_{2}\right]$ & $\mathbf{( 3 a})$ & \multirow{2}{*}{$\mathrm{NMe}_{2}$} & 0.60 & -2.07 \\
\cline { 1 - 2 }$\left[\left\{\mathrm{Cu}\left(\mathrm{YNC}_{10} \mathrm{H}_{14} \mathrm{O}\right)\right\}_{2}(\mu-\mathrm{Br})_{2}\right]$ & $\mathbf{( 4 a )}$ & & 0.65 & -2.09 \\
\hline$\left[\left\{\mathrm{Cu}\left(\mathrm{YNC}_{10} \mathrm{H}_{14} \mathrm{O}\right)\right\}_{2}(\mu-\mathrm{Cl})_{2}\right]$ & $\mathbf{( 3 b )}$ & \multirow{2}{*}{$\mathrm{NHMe}$} & 0.62 & $-2.18^{\mathrm{b}}$ \\
\cline { 1 - 2 }$\left[\left\{\mathrm{Cu}\left(\mathrm{YNC}_{10} \mathrm{H}_{14} \mathrm{O}\right)\right\}_{2}(\mu-\mathrm{Br})_{2}\right]$ & $\mathbf{( 4 b )}$ & & 0.67 & $-2.23^{\mathrm{c}}$ \\
\hline
\end{tabular}

${ }^{\text {a }}$ Values $( \pm 10 \mathrm{mVolt})$ in THF $(v=200 \mathrm{mV} / \mathrm{s})$. Processes are quoted as reversible although they do not obey to the criteria $\mathrm{i}_{\mathrm{pa}} / \mathrm{i}_{\mathrm{pc}}=1$. ${ }^{\mathrm{b}} \mathrm{A}$ weak wave is observed at $E_{1 / 2}^{\text {red }}=-1,20 \mathrm{~V}$. ${ }^{\mathrm{c}}$ A weak wave is observed at $E_{1 / 2}^{\text {red }}=-1,32 \mathrm{~V}$

\section{CPE studies}

The cyclic voltammograms show that the two $\mathrm{Cu}(\mathrm{I})$ centres have similar electronic properties in spite of their linear and tetrahedral geometries.

In order to get further information in the processes, controlled potential electrolysis was performed at the potentials of the anodic waves.

A count of two electrons per molecule was obtained as expected for the oxidation $\mathrm{Cu}(\mathrm{I}) \rightarrow \mathrm{Cu}(\mathrm{II})$ of two metal sites in $\left[(\mathrm{CuX})_{2}\left(\mathrm{H}_{2} \mathrm{NNC}_{10} \mathrm{H}_{14} \mathrm{O}\right)\right]_{\mathrm{n}}(\mathrm{X}=\mathrm{Cl}, \mathbf{1 c} ; \mathrm{Br}, \mathbf{2 c})$. In contrast, the electron count was one electron per molecule in the case of complex $\left[(\mathrm{CuCl})_{2}\left(\mathrm{MeHNNC}_{10} \mathrm{H}_{14} \mathrm{O}\right)\right]_{\mathrm{n}}(\mathbf{1 b})$ or slightly higher than one $(1,3)$ electron per molecule in the case of compound $\left[(\mathrm{CuCl})_{2}\left(\mathrm{Me}_{2} \mathrm{NNC}_{10} \mathrm{H}_{14} \mathrm{O}\right)\right]_{\mathrm{n}}(\mathbf{1 a})$. The data obtained by CPE indicate that the electrochemical behaviour of the coordination polymers is driven by the characteristics of the substituent at the camphor ligand $(\mathrm{Y})$ in contrast to the redox potentials $(\mathrm{CV})$. An electron count less than two (1a and $\mathbf{1 b})$ suggests that upon one electron oxidation the rupture of the chain $-\mathrm{Cu}-\mathrm{Cl}-\mathrm{Cu}-\mathrm{Cl}$ - occurs, forming $\mathrm{CuCl}_{2}$ plus a copper species $\left(\{\mathrm{CuL}\}^{+}\right)$ that does not oxidize at the potential of CPE (1) or further reacts (1a). In the last case nucleophilic attack by fluoride (formed from the electrolyte $\left[\mathrm{Bu}_{4} \mathrm{~N}\right]\left[\mathrm{BF}_{4}\right]$ ) at the cationic species could afford a neutral fluoride species $(\mathrm{L}-\mathrm{Cu}-\mathrm{F})$ that could oxidize at the potential of CPE and account for more 0.3 electrons (total, $1+0.3$ electrons). The number of electrons (0.3) would be controlled by the kinetics of formation of the fluoride species. A point in favour of the formation of this fluoride species from 1a is that an electron count equal to one is obtained when $\mathrm{CPE}$ is made using $\mathrm{LiClO}_{4}$ as electrolyte in agreement with no fluoride attack being feasible.

$\mathrm{CPE}$ of dimer complexes $\left[\left\{\mathrm{Cu}\left(\mathrm{YNC}_{10} \mathrm{H}_{14} \mathrm{O}\right)\right\}_{2}(\mu-\mathrm{X})_{2}\right](\mathrm{X}=\mathrm{Cl}, \mathrm{Br})$ was also performed at the potential of the anodic processes. As expected, two electrons per molecule were transferred in complexes $4 \mathbf{a}$ and $\mathbf{4 b}$, although the value is slightly higher than two in $\mathbf{4 b}$. CPE data from 3a $\left[\left\{\mathrm{Cu}\left(\mathrm{Me}_{2} \mathrm{NNC}_{10} \mathrm{H}_{14} \mathrm{O}\right)\right\}_{2}(\mu-\right.$ $\mathrm{Cl})_{2}$ ] show that 1.3 electrons per molecule are transferred rather than the expected two for a process involving the oxidation $\mathrm{Cu}(\mathrm{I}) \rightarrow \mathrm{Cu}(\mathrm{II})$ of two metal sites. The electrochemical behavior of compounds 1a and 3a can be related with their ability to interconvert $(\mathbf{1 a} \rightarrow \mathbf{3 a}$ and $\mathbf{3 a} \rightarrow \mathbf{1 a})$ [3]. The species $\{\mathrm{LCuF}\}$ may be considered as an intermediate in polymer to dimer conversion promoted by 
oxidation considering the weakening of the $\mathrm{L}-\mathrm{Cu}^{+} \ldots . \mathrm{Cl}-\mathrm{Cu}-\mathrm{Cl}$ bond induced by electrochemical oxidation followed nucleophilic attack by the halide.

In a tentative to get further insight into the oxidation process the reaction of $\left[(\mathrm{CuCl})_{2}\left(\mathrm{Me}_{2} \mathrm{NNC}_{10} \mathrm{H}_{14} \mathrm{O}\right)\right]_{\mathrm{n}}$ and $\quad\left[\left\{\mathrm{Cu}\left(\mathrm{Me}_{2} \mathrm{NNC}_{10} \mathrm{H}_{14} \mathrm{O}\right)\right\}_{2}(\mu-\mathrm{Br})_{2}\right] \quad$ with ferricinium was undertaken. In the reaction formation of the $\mathrm{Cu}$ (II) halide $\left(\mathrm{CuX}_{2}\right)$ was corroborated analytically and following the oxidations of $\mathbf{1 a}$ and $\mathbf{4 a}$ with $[\mathrm{FcH}]^{+}\left[\mathrm{BF}_{4}\right]^{-}$by ${ }^{19} \mathrm{~F}$ NMR are observed shifts in the $\left[\mathrm{BF}_{4}\right]^{-}$signal (1a, from -149.4 ppm to $-147.2 \mathrm{ppm}$ and in $4 \mathrm{a}$ from $-149.4 \mathrm{ppm}$ to $-146.6 \mathrm{ppm}$ ) that suggest formation of a different cationic species which we formulated as $[\mathrm{CuL}]^{+}$ $\left[\mathrm{BF}_{4}\right]^{-}$. Small shifts in the ${ }^{19} \mathrm{~F}$ NMR spectra are known to accompany transfer of $\left[\mathrm{BF}_{4}\right]^{-}$from one metal to the other $[7,8]$. Further evidence for $[\mathrm{CuL}]^{+}$comes from the IR spectra that display a considerable shift to higher values of $v_{\mathrm{CO}}(1762$ $\left.\mathrm{cm}^{-1}\right)$ and $v_{\mathrm{CN}}\left(1663 \mathrm{~cm}^{-1}\right)$ compared to the corresponding in 1a $\left(v_{\mathrm{CO}}=1691 ; v_{\mathrm{CN}}\right.$ $=1550 \mathrm{~cm}^{-1}$ ). Such shifts may be attributed to the cationic character of $\{\mathrm{CuL}\}^{+}$. Although a complete characterization of the species formed by chemical or electrochemical oxidation could not be done, at least we verified that the reactivities of the dimethyl hydrazone $\left(\mathrm{Y}=\mathrm{NMe}_{2}\right) \mathrm{Cu}(\mathrm{I})$ polymer or dimer complexes follow the same trend by electrochemical or chemical oxidation. Calculations to get a better understanding of the processes are in progress.

\section{Acknowledgments}

To Fundação para a Ciência e Tecnologia (FCT) for financial support through a $\mathrm{PhD}$ grant to T.A. Fernandes (SFRH/BD/48331/2008).

\section{References}

1. M.F.N.N. Carvalho, M.T. Duarte, Rudolf Herrmann, Collect. Czech. Chem. Commun. 71 (2006) 302-310.

2. M.F.N.N. Carvalho, A.S.D. Ferreira, J.L. Ferreira da Silva, L.F. Veiros, Collect. Czech. Chem. Commun. 72 (2007) 649-665.

3. M.F.N.N. Carvalho, T.A. Fernandes, A.M. Galvão, H.-A. Krug von Nidda, M.A.P. Sampaio, Inorg. Chim. Acta 363 (2010) 71-76.

4. M.F.N.N. Carvalho, M.T. Duarte, T.A. Fernandes, A.M. Galvão, A.M. Botelho do Rego, Inorg. Chem. 49 (2010) 10330-10337.

5. (a) M.O. Forster, T.J. Thornley, Chem. Soc. 95 (1909) 942-956;

(b) V.M. Kolb, A.C. Kuffel, H.0. Spiwek, T.E. Janota, J. Org. Chem. 54 (1989) 2771-2775.

6. M.F.N.N. Carvalho, Port. Electrochim. Acta 22 (2004) 3-10.

7. V.N. Plakhotnyka, R. Schmutzlerb, L. Ernstb, Y.V. Kovtuna, A.V. Plakhotnyka, J. Fluorine Chem. 116 (2002) 41-44.

8. M. Ghiladi, K.B. Jensen, J. Jiang, C.J. McKenzie, S. Mørup, I. Søtofte, J. Ulstrup, J. Chem. Soc., Dalton Trans. (1999) 2675-2681. 